\title{
Personal assistance in Sweden - Support and service for persons with certain functional impairments
}

\author{
Kerstin Gynnerstedt and Hans Bengtsson
}

Kerstin Gynnerstedt, PhD, is Associate Professor, School of Social Work, Linnaeus University. Hans Bengtsson, PhD, is Associate Professor, School of Social and Health Sciences, Halmstad University.

\begin{abstract}
The political goal and the aim of Swedish disability policy today is to give persons with disabilities the same opportunities as others to participate in society and to live together with others - the principles of normalisation and integration. Two particular acts came into force on the 1st of January 1994, the Act concerning Support and Service for Persons with Certain Functional Impairments (LSS) and the Act concerning Assistance Compensation (LASS). LSS gives persons with severe functional disabilities, either physical or mental, the legal right to 10 different kinds of support and services. One of the most important elements in LSS is the right to personal assistance. The idea of personal assistance is to provide support that is tailor-made to the individual as far as possible and to optimise the person's influence over how the support is arranged. The aim of this article is to describe and analyse the right personal assistance from an administrative perspective. The focus is on the application and decision process and the development of this support during the years.
\end{abstract}

\section{Introduction}

Disability policy has recently evolved from a medical perspective with focus on care and treatment to a political focus on rights and equality in society. Political pressure has led to comprehensive government inquiries, reports and changes of current legislation during the last 20 years. The political goal and the aim of Swedish disability policy today is to give persons with disabilities the same opportunities as others to participate in society and to live together with others - the principles of normalisation and integration. The basis for the Swedish welfare programmes is a belief in solidarity and equality - a sense of collective responsibility. As part of this responsibility there is a visible commitment in the legal framework to provide support to persons with disabilities to enable them to maintain a standard of living similar to that of others (Hollander, 1996).

Previously those with extensive need of support were not being provided with the kind of personal assistance they needed. Many of them had no influence whatsoever over the help they received in very intimate situations and the help was often provided by a large number of different persons coming and going in their home. The idea of personal assistance is to provide support that is tailor made to the individual as far as possible and to optimise the person's influence over how the support is arranged. 
The National Board of Health and Welfare (Socialstyrelsen) carried out international comparative research concerning personal assistance some years ago. The study showed that personal assistance is paid support given in various settings to enable persons with severe disabilities to participate in mainstream activities. Some forms of personal assistance is now available (often by statutory right) in all Nordic countries, most western European countries, Australia, parts of Asia, the US and Canada. The naming of personal assistance may vary from country to country. This is often related to legislative categories, rather than types of interventions (Socialstyrelsen, 2007). The aim of this article is to describe and analyse the right to personal assistance in Sweden from an administrative perspective. The focus is on the application and decision process and the development of this support during the years.

\section{The 1994 disability reform in Sweden - new rights for persons with certain functional impairments}

Two particular Acts came into force on the 1st of January 1994, the Act concerning Support and Service for Persons with Certain Functional Impairments (LSS) (SFS, 1993:387) and the Act concerning Assistance Compensation (LASS) (SFS, 1993:389). LSS gives persons with severe functional disabilities, either physical or mental, the legal right to 10 different kinds of support and services. The law concerns rights. It is about being able to do everything that an able-bodied person normally does. LASS is a complementary law to LSS.

Those who will benefit from these rights are persons with severe disabilities. Under the former Special Service Act (SFS 1985:568) persons with learning disability, autism and braininjury already had some of the rights contained in the new Act. These persons received help automatically but had also some new rights. One of the most important changes was that they were to be regarded as full and equal members of the local community when the responsibility for their care was removed from the county council to the local government.

LSS comprises the following 10 measures for special support and special services: Advice and personal support; Personal assistance; Companion service; Contact person; Relief service in the home; Short-term stay away from home; Short-term minding of school children over 12; Foster homes and special housing for children and young people; Special housing for adults and Daily activities (not work).

Two other Acts are also important for persons with disabilities. The Social Services Act (SFS, 2001:453), which concerns the basic responsibility that local authorities have for the whole population, and the Health and Medical Services Act, which sets out the responsibility that county councils have for health and medical care.

\section{The right to personal assistance}

One of the most important elements in LSS is the right to personal assistance. LSS and LASS replaced the former Act of Special Services and enlarged at the same time the affected group. The service is an individual right and specific service, which the individual has to apply for. If the application is turned down there is a right to appeal to a higher court. This provides a control function, which also is exercised by the National Board of Health and Welfare and the county council. These laws are seen to be the most complex ones in the whole social insurance system, partly because there is a great need for cooperation between 
different local authorities and partly because the laws have brought about interpretation and implementation problems.

Those who might obtain personal assistance in accordance with these two Acts are divided into three groups:

1. Persons with learning disabilities, with autism or conditions similar to autism,

2. Persons with considerable intellectual disabilities / learning disabilities as a result of brain injury in adult age (acquired brain injury),

3. Persons with other major and permanent disabilities which cause considerable need for support and services and where the disability is not caused by a normal process of ageing.

The individual has to apply for the services. The local authority where the individual is living has the ultimate responsibility. A needs assessment is done by officials from social services and sometimes it is done together with officials from the local Social Insurance Office ${ }^{1}$. When the basic needs of services exceed 20 hours a week the financial responsibility continues through the National Social Insurance according to LASS, which means financing by state money.

A supplement to the LSS Act in 1996 defined more precisely what needs personal assistance should cover. Personal assistance was defined as:

... personal modelled services given to a limited number of individuals who because of major and permanent disabilities need help with personal hygiene, meals, dressing and undressing, communication with other people and other kinds of help that requires thorough knowledge about disabled person (fundamental needs). Persons with such needs within the three groups mentioned above have the right to receive personal assistance (Government Bill, 1995/96:146).

The Social Insurance Offices do not deliver services and are not employers for those who deliver the services. Persons with disabilities, who are granted reimbursement, can choose either to employ somebody as a personal assistant or to ask local authorities or somebody else to deliver the services. The reimbursement assistance is designed to cover salary costs and other fees in relation to the delivered services.

\section{The decision-making process}

The LSS and LASS reforms are based on participation from individuals in the target group themselves. The investigation starts with either an application from the disabled person him/herself or with a report from officials in Social Services or from a rehabilitation clinic in a hospital. There have often been social services delivered for a longer or shorter time already before the application for LSS, to the Social Service Act 2001. Sometimes it is social workers from the rehabilitation clinic at the hospital who take the initiative for personal assistance. Applications from the disabled person him/herself are less common, even if they formally are doing the application.

With all these authorities involved there is a great need for cooperation between them to combine the different kinds of services to the individual.

Social Service Officials and Social Insurance Officials are often educated professional social workers. 


\section{Group criteria assessment}

The distribution of cases among staff at the Social Insurance Office (the organisation responsible for the investigation and the needs assessment process) varies, with date of birth and geographical area being the most common factors in distribution. At smaller offices there is often a certain degree of specialisation and cases with personal assistance are centralised. Most officials also deal with applications for other kinds of disability benefits. A combination of medical, social and psychological factors is the base for the assessment of personal assistance.

An investigation process begins by assessing the group criteria - to see if the disabled person is included in one of the three groups entitled to special services and then if the next criteria are fulfilled. These criteria consider whether the person's condition is chronic, leading to considerable difficulties in everyday life and causing comprehensive needs.

It can be difficult to decide the duration of a disability especially if the person is in a rehabilitation phase and the condition is not yet stable. Other difficulties occur with applicants with complex disabilities including psychiatric diagnosis or a disease with poor prognosis.

There are many problematic cases and situations to assess. One is concerning personal assistance for children. What is the normal parent responsibility for children in general at different ages? How much help and time does a one-year-old child normally need and what is the need for children aged 10? As children grow, their independence will normally increase so that they need less and less support from their parents. When it comes to children with disabilities they need a lot more support and for those the normal parent responsibility needs to be supplemented by other kinds of support. For children with a comprehensive need of care (often around the clock) or with multiple disabilities, there is a right to personal assistance. Assistance compensation for time when the child is in childcare, school or daily activities can be allowed only if there are very special reasons. Personal assistance shall not become a substitute for the number of staff normally required.

Another problematic situation is the responsibility of couples to each other in a marriage. What kind of support and how much personal assistance are you obliged to give the partner you are living with? Again, what is the boundary between the responsibilities for medical care and social services concerning, for example, persons with terminal cancer? What is then meant by the criteria 'long duration' - a certain amount of months or is it for the rest of life? What kind of services are needed - help with daily life activities or a lot of advanced medical treatment? It seems sometimes ethically dubious to discuss these more economic-based responsibilities in cases like this, but there are important questions of both who is responsible for the services and who is paying. What is self-care and what is medical care?

\section{Needs assessment step one}

The personal assistance service is restricted to persons with severe disabilities, those who need help in very demanding and complicated situations of very personal character. To get access to this particular service the disabled person will need help with what is labelled basic needs exceeding 20 hours a week. The needs must include help with personal hygiene, meals, dressing and undressing, communication with others or other kinds of help presupposing intimate knowledge about the person with disability. There are problems with the definition of 'basic needs' and also how you estimate the time that is used for these activi- 
ties. Other questions concern the relationship between a particular handicap and the needs of an individual. What kind of consideration is adequate to individual differences and to different disabilities? The normal method used by officials is that they make a home visit and ask the person with the disability him/ herself to report what happens during a day and to describe the different activities they need help with and how long they take. Sometimes an occupational therapist or a physiotherapist is consulted to obtain a more technical and standardised structured needs assessment.

\section{Needs assessment step two}

If the basic needs exceed 20 hours a week the Social Insurance officials have to investigate additional personal needs in daily life. Daily life is here referred to as expected, continuous, daily or frequent activities or everyday situations. It can for example include household activities like cooking and cleaning but also attending social activities in the municipality, like going to a movie or a theatre. The level of daily activities is considered in relation to the kind of life that is normal for those of the same age and at the same place.

\section{The decision-making process}

Between 1994 and 2008, the Social Insurance Organisation had special Social Insurance Committees for decision-making in individual cases. These local committees were composed of seven elected members including a chairman. Five were elected from the political parties represented in the local county council and the other two members were elected from labour market organisations. Elections to these committees took place every fourth year and the members took up their duties on April 1 the year after the ordinary political election. These members were laypersons supposed to contribute with life experience and knowledge from society. Members had to be objective and not represent their political parties. The committee was supposed to represent different ages, sexes and ethnic backgrounds in order to diminish risks for discrimination and to promote the legal rights of the individual.

The number of cases should not exceed 40-45 at each committee meeting, including all different types of social insurance cases. Normally there were only a few cases concerning personal assistance each committee meeting. Before the application was finalised by the committee the individual applicant had the right to be informed about everything included in the investigation and the proposed decision. If he/she disagreed with the facts and conclusion they could appeal in writing or in person. In reality very few came to the committee meetings, though some gave written comments. Normally the original proposal from the official was also the final decision. After the committee meeting the applicant received a written report with the decision and information about appeal options (Bengtsson \& Gynnerstedt, 2003).

This decision process was changed in 2008 when the Social Insurance Committees were closed down. The application process has not changed since then but since 2008, decisions are made by officials on different administrative levels in the Insurance Offices. The purpose of the changes was to improve the decision-making process (to make it less time consuming), and thereby increase efficiency.

\section{The development of state financed assistance}

The development and the design of state financed personal assistance have been discussed since the reform was carried out in 1994, both in terms of interpretation and implementation 
problems and increased financial costs. The costs have increased from close to SEK 4 billion in 1995 to more than SEK 18 billion in 2007 (SOU 2008:77:170).

Table one. Development of costs over time from 1997

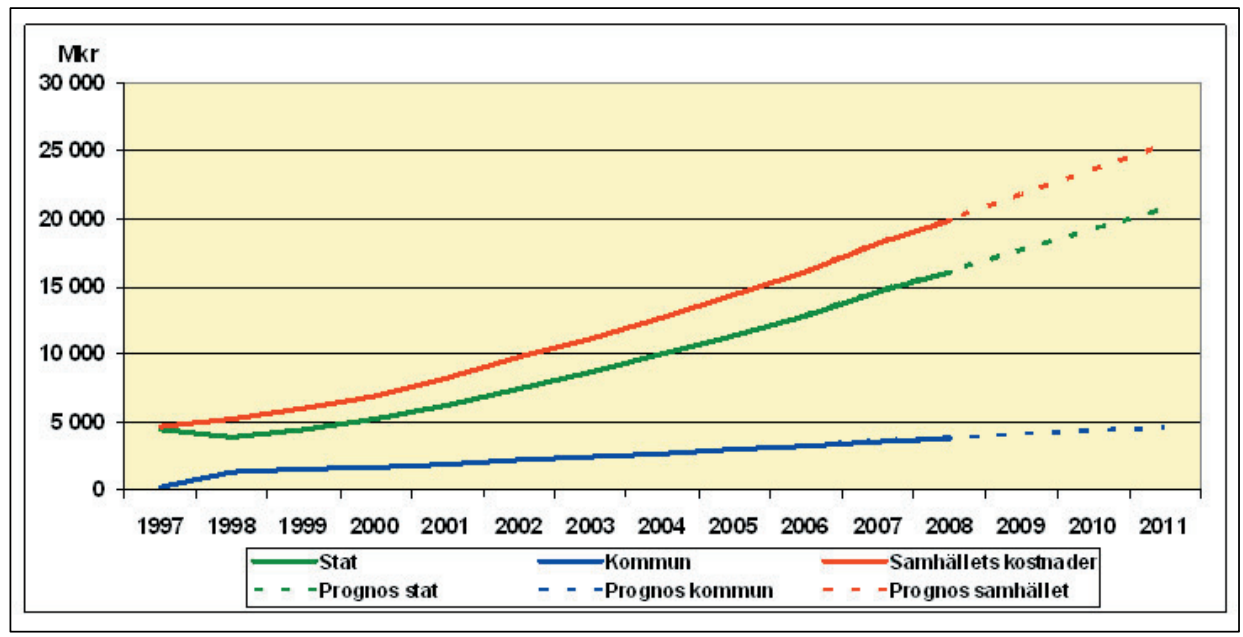

Source: Försäkringskassan http: / / www.forsakringskassan 20100620

The development of costs has mainly been explained as being due to both an increase in the number of service recipients and because the average number of hours per recipient have increased (SOU 2008:77:171).

The increase of costs has been worrying for the state and the latest state investigation focused on how to reduce future increases. Changes for the future are a more restrictive control of providers, especially private entrepreneurs and cooperatives, and more demands on efficiency in the services. All private providers will need a certificate from the county administrative board. There will also be a responsibility for supervision to be carried out by the county administrative board (Prop 2009/10:176).

\section{A field for state commissions during the years}

An important feature of the wide-ranging personal assistance reform programme was to give disabled persons the right to independence and autonomy with a personal assistance free of charge for the individual. It was remarkable that the legislation for this reform was passed through Parliament without major disagreement between political parties. Since the initial commission, a society for all (SOU 1992:52), there have been a number of state commissions and public investigations by central government organisations. The focus has been on cost analysis (SOU 1995:126; Socialstyrelsen, 1995; Socialstyrelsen, 1997a, b), treatment (SOU 1999:21; SOU 2008:77), welfare for people with disabilities (SOU 2001:56) and administration (SOU 2001:47). Recently, the state commissions have dealt with different forms of current and future funding regulations and forms of delivery and employment of personal assistants. However, due to the powerful disability organisations and their lobbying activities most of the changes and limitations proposed by the national commissions have not been accepted by Parliament. Government has made minor changes in the decision-making process and 
in the administration of personal assistance in order to reduce the increase of costs and to get closer control of the delivery and quality of the services. The results have been a more restrictive administration and application process with supervision. The estimation for the future is that despite these changes costs will rise for several more years (see table 2).

Table two.

\begin{tabular}{|c|c|c|c|c|c|c|}
\hline \multirow{2}{*}{$\begin{array}{l}\text { År 1) } \\
\text { Year }\end{array}$} & \multicolumn{2}{|l|}{ Samtliga/Total } & \multicolumn{2}{|c|}{ Kvinnor/Women } & \multicolumn{2}{|l|}{ Män/Men } \\
\hline & $\begin{array}{c}\text { Antal A } \\
\text { personer } \\
\text { Number of } \\
\text { persons }\end{array}$ & $\begin{array}{r}\text { Intal timmar } \\
\text { per vecka i } \\
\text { medeltal } \\
\text { Granted } \\
\text { hours/week }\end{array}$ & $\begin{array}{r}\text { Antal } \\
\text { personer } \\
\text { Number of } \\
\text { persons }\end{array}$ & $\begin{array}{r}\text { Antal timmar } \\
\text { per vecka i } \\
\text { medeltal } \\
\text { Granted } \\
\text { hours/week }\end{array}$ & $\begin{array}{r}\text { Antal } \\
\text { personer } \\
\text { Number of } \\
\text { persons }\end{array}$ & $\begin{array}{r}\text { Antal timmar } \\
\text { per vecka i } \\
\text { medelta } \\
\text { Granted } \\
\text { hours/week }\end{array}$ \\
\hline 1994 & 6138 & 659 & 2837 & 657 & 3301 & 661 \\
\hline 1995 & 7283 & 676 & 3338 & 676 & 3945 & 676 \\
\hline 1996 & 7666 & 706 & 3544 & 704 & 4122 & 709 \\
\hline 1997 & 7861 & 755 & 3687 & 747 & 4174 & 762 \\
\hline 1998 & 8102 & 80 & 3803 & 790 & 4299 & 809 \\
\hline 1999 & 9085 & 834 & 4239 & 820 & 4846 & 846 \\
\hline 2000 & 9684 & 865 & 4570 & 850 & 5114 & 878 \\
\hline 2001 & 10849 & 887 & 5114 & 873 & 5735 & 899 \\
\hline 2002 & 11616 & 92 & 5490 & 901 & 6126 & 937 \\
\hline 2003 & 11910 & 959 & 5619 & 937 & 6291 & 979 \\
\hline 2004 & 12751 & 987 & 6017 & 965 & 6734 & 1007 \\
\hline 2005 & 13576 & 1013 & 6414 & 990 & 7162 & 1034 \\
\hline 2006 & 14319 & 1036 & 6759 & 1014 & 7560 & 1056 \\
\hline 2007 & 15183 & 1059 & 7181 & 1038 & 8002 & 1078 \\
\hline 2008 & 15462 & 1083 & 7272 & 1066 & 8190 & 1098 \\
\hline 2009 & 15858 & 1106 & 7432 & 1093 & 8426 & 1118 \\
\hline
\end{tabular}

An essential change concerning the democratic influence in the administrative process occurred when the committees in the Social Insurance Offices were replaced by another official. The question is what this change means to the democratic transparency of the process and to the confidence of applicants in the process, as well as levels of support for the services in civil society. However, despite all the efforts to carry out individually adjusted services to persons with severe disabilities, a report has recently been published saying that despite the reforms inequality persists in many fields in society (Socialstyrelsen, 2010).

\section{A field to research}

The personal assistance service can be analysed in many ways. Service user research carried out by social work and other students has focused on their own experiences and the extent to which the rights and opportunities for self-fulfilment are supported by legislation and policies (Jacobsson, 1996; Larsson, 2008; Roos, 2009). Other theses focus on the consequences of and the conditions for self-determination, independence and user participation for persons with different kinds of disabilities. The Swedish purchaser/provider system has been scrutinised by Hugemark (2006). 
However, there is little research concerning the policy development and administration of personal assistance though it is such a comprehensive reform and costly for both local authorities and the state. Ten years ago we were commissioned by the National Social Insurance Committee to investigate why the costs for personal assistance had increased so much and to predict future costs. We interviewed officials both in Social Insurance Offices and local authorities / social services from Malmö in the south to Luleå in the north of Sweden. We also met members of different disability organisations at the same places. Our research was complemented by statistical studies and internal act reviews done by the National Insurance Office.

The result of our costs investigation showed that it was due to several reasons. Firstly, the reform was not completely financed from the beginning 1994. Secondly, the needs of persons with disabilities, who already had assistance, have increased - they have grown older and frailer and they have become reliant on personal assistance. Thirdly, new groups with disabilities were entering the system. Fourthly, changes in the environment, that created new personal assistance needs, had an impact, as did claims for a satisfactory working environment for the assistants. The prospect for the future was that the costs would continue to increase year by year (RFV 2001:3) and that is what has happened in the years since this research (see table 1).

As a result of this research, we obtained information concerning the investigation and decision-making process, steering problems, as well as the working relationships between the two authorities (Social Service Office and Social Insurance Office) involved in the administrative process. We noted these issues in our report to the National Social Insurance Committee and were able to use the information in a subsequent research project during 2000-2002 with the aim of describing and analysing LSS and LASS intentions in relation to the way the reform was exercised in practice on different administrative levels (RFV analyserar, 2001:3; Bengtsson \& Gynnerstedt, 2003).

The Social Insurance Offices on local and regional level were our main research focus but the National Social Insurance Office and central political bodies were also included in our analyses. The project covered the time period from 1994-2001, for example, the first eight years of the reform. The empirical study on a regional level covered Social Insurance Offices in three different counties in Sweden with both urban and rural areas. The development of several changes in regulation concerning the application and decision process and the purchaser and provider system has created new research questions, but also a need for a follow-up of previous research to give a chance for a more longitudinal approach.

\section{Theoretical perspective}

These disability research questions can be analysed using different theories concerning the policy process, administration, steering activities and control. Here we focus on just two theories as examples - the policy learning perspective and the street level bureaucracy perspective.

\section{Policy learning perspective}

This perspective is built upon the idea that you cannot view the political administrative process (policy process) as simply the implementation of certain policy aims. Other factors, such 
as policy learning and policy development are involved. The study of learning processes can be focused on internal and external factors (Howlett \& Ramesh, 1995). The different phases with initiating, preparation, decision, implementation and evaluation cannot be regarded as defined in a fixed policy process but instead as a recurrent process (Nakamura \& Smallwood, 1980). In the reforming of LASS a number of important changes in certain sections have been made in the light of experience. Also the goals can be modified during the process due to unexpected events, lack of policy theory, new economic conditions, party political strategies, and shifting opinions in the environment. To set up such a change-oriented and reactive approach can be regarded more as a well thought-out strategy for complex social reforms than ad-hoc solutions. That is the case with the disability reform.

In this process there is a developmental discovery of how the resources have to be used, what strategy is valid and how problems have to be solved (Colebatch, 1998). It can happen by special education and continuing education but also by reflecting on past experiences. One aspect of learning is socialisation in a certain administrative culture (Wilson, 1989). It is, for example, common that new employees learn from older more experienced colleagues. This socialisation is not always voluntary or conscious (March \& Olsen, 1989). Changes can also happen through adjustment to other circumstances like different technical, social or structural changes. Learning by routines, for example, by picking up knowledge and experiences in special procedures, increase the possibilities for coordination of different activities and avoiding conflicts. New situations are met by activities already developed in the organisation (Lundquist, 1992).

\section{Street level bureaucracy perspective}

Bureaucratic organisations are arranged in hierarchical ways with different levels managing different activities and functions. Some officials work far away from the front line, others are professional investigators, consulting and treating functions in direct contact with citizens. Although one can find these categories of officials in rather different working situations, they work under similar conditions. At the end of 1960 an American political scientist Michael Lipsky presented his theory about street level bureaucrats (Lipsky, 1980).

This theory places officials in close contact with clients, patients and customers. Decisions made by these bureaucrats, and the routines, procedures and norms they established give them a particular power position. In reality they can interpret or change the content of the political decisions so when implemented, they become quite different from what was intended (Wilson, 1996). That turns street level bureaucrats into policy makers. The street level bureaucrats have discretion over who gets the most appropriate services. The client understands that the officials have these decision-making powers which affect their lives. Consequently, street level bureaucrats become policy evaluators and politicians find them hard to control.

The most important characteristic of street level bureaucrats is the kind of work they perform and their relation to their clients. These relations can easily result in conflict between the different demands being made. The client looks upon the situation from his/her angle and wants service according to what they think are their rights. Needs are according to personal experiences and expressed that way, but they are assessed by street level bureaucrats in an objective and comprehensive way (Socialstyrelsens Allmänna Råd, 1994:1:23). Without suitable rules to follow the official might apply different interpretations and have 
freedom to act, which can cause arguments and negotiations with the client about different solutions. The officials can also face conflict between their different roles where democratic values like participation and legal rights of the individual confront economic values like efficiency and rationality (Lundquist, 1998).

To manage demanding tasks street level bureaucrats are forced to simplify the activities by introducing different types of routines and praxis (Agevall, 1994). Also the authorities try to construct useful categories for different cases (people-processing). By these standardised categories citizens become a client or a case. This categorisation can counteract the careful individual assessment that is intended by the law (Hetzler, 1994).

\section{Concluding remarks}

A successful implementation of the rights legislation is dependent on high levels of public legitimacy, in which authorities, citizens and other involved actors are willing to accept the intentions of the law. Primarily, it is a question of paving the way towards a general recognition of the democratic agreement that the needs of persons with certain functional impairments are given priority. The process of implementation relies on several aspects of legitimacy concerning political, professional and civil actors. While the political legitimacy seems to be consistent when it comes to the national level, there is significant resistance from local governments. This may be explained by the fact that the reform intervenes on the treasured local autonomy, but also by the fact that it leaves a central responsibility for financing to the local level. Such a reform is always challenging, especially in Sweden where municipalities bear a significant welfare responsibility.

When it comes to professional agents, research underlines the importance of street level bureaucrats' willingness, capacity and knowledge as prerequisites for implementing the reform intentions. Furthermore, one must pay attention to the role of courts, equally involved in legal interpretations. The Swedish experience is that rights legislation usually leads to intricate legal situations as courts read the law differently. This may cause further legitimacy problems as the legal procedures give little guidance on how to control an already substantial local variation.

However, the reform has important support within the civil society. Representatives of disability organisations have encouraged the law since the very start. The earlier procedures characterised by civil cooperation (through commissions of elected members) and transparency, should also have contributed to create legitimacy among both the involved actors and the public. By contrast, the new procedures, concentrated as they are on efficiency, both regarding expenditures and timeframes, may have negative consequences. The officials / professionals have been assigned increased responsibility at the expense of the elected representatives. This change of focus may damage the legal security, and consequently its legitimacy. Nevertheless, the most crucial legitimacy question should be whether or not the measures reach out to those with the greatest needs. So far, the answer to this question is not evident and requires further research.

\section{Authors' contact details}

Dr Kerstin Gynnerstedt, School of Social Work, Linneaus University, SE-351 95 Växjö, Sweden. E-mail: kerstin.gynnerstedt@lnu.se 
Hans Bengtsson, School of Social and Health Sciences, Box 823, SE-30118 Halmstad University, Halmstad, Sweden. E-mail: hans.bengtsson@hh.se

\section{References}

Agevall, L. (1994). Beslutsfattandets rutinisering. Lund: Lund Political Studies.

Bengtsson, H., \& Gynnerstedt, K. (2003). Assistansreformen i politik och forvaltning. Malmö: Harec.

Colebatch, H.K. (1998). Policy. Buckingham: Open University Press.

Government Bill 1995/96: 146. Questions about personal assistance.

Hetzler, A. (1994). Socialpolitik i verkligheten. Lund: Bokbox förlag.

Hollander, A. (1996). Rättighetslag $i$ teori och praxis. Uppsala: Iustus Förlag.

Howlett, M., \& Ramesh, M. (1995). Studying public policy. Toronto: Oxford University Press.

Hugemark, A. (2006). Mellan marknad och politik: om statlig styrning av marknaden för personlig assistans. FoU-rapport / Forsknings-och utvecklingsenheten, Stockholms stad.

Hugemark, A., \& Wahlström, K. (2002). Personlig assistans i olika former: mål, resurser och organisatoriska gränser. FoU-rapport / Forsknings- och utvecklingsenheten, Socialtjänstförvaltningen, Stockholms stad, 2002:4

Jacobsson, A. (1996). Röster från en okänd värld. Hur människor med fysiska funktionshinder och omfattande hjälpbehov upplever sina existensvillkor. Stockholms Universitetet pedagogiska institutionen. Diss.

Larsson, M. (2008). Att förverkliga rättigheter genom personlig assistans. Lund: Socialhögskolan. Lund dissertations in social work.

Lipsky, M. (1980). The street level bureaucracy. Dilemmas of the individual in public service. New York: Russel Sage Foundation.

Lundquist, L. (1992). Förvaltning, stat och samhälle. Lund: Studentlitteratur.

Lundquist, L. (1998). Demokratins väktare. Lund: Studentlitteratur.

March, J. \& Olsen, J. P. (1989). Rediscovering institutions. New York: The Free Press.

Nakamura, R. K., \& Smallwood, F. (1980). The politics of policy implementation. New York: St Martiń s Press.

Prop 2009/10:176. Personlig assistans och andra insatser - åtgärder för ökad kvalitet och trygghet.

SFS. 1985:568. Lagen om särskilda omsorger om psykiskt utvecklingsstörda. The special service Act.

SFS. 1993:387. Lag om stöd och service till vissa funktionshindrade (LSS). (In Swedish). The Act concerning Support and Services for Persons with Certain Functional Impairments.

SFS. 1993:389. Lag om Assistansersättning. The Act Concerning Assistance Compensation.

SFS. 2001:453. Socialtjänst lagen - The Social Services Act.

Roos, J. M. (2009). Quality of personal assistance: Shaped by governments, markets and corporations. Gothenburg: Department of Psychology, University of Gothenburg. Diss.

RFV analyserar. 2001:3. Resurser för att leva som andra-en analys av kostnadsutvecklingen inom assistansersättningen. Stockholm: Riksförsäkringsverket.

Socialstyrelsens Allmänna Råd 1994:1. Stockholm.

Socialstyrelsen. (1995). Den statliga assistansersättningen - Varför så många timmar? Socialstyrelsen följer upp och utvärderar 1995:3.

Socialstyrelsen. (1997a). Vad kostade handikappreformen? Socialstyrelsen följer upp och utvärderar 1997:1.

Socialstyrelsen. (1997b). Handikappreformen Slutrapport 1997. Socialstyrelsen följer upp och utvärderar 1997:4.

Socialstyrelsen. (2007). Umbrella Review: The effectiveness of personal support in different populations. University of Oxford Centre for Evidence-Based Intervention.

Socialstyrelsen. (2010). Alltjämt ojämlikt. Stockholm.

SOU. 1992:52. Ett samhälle för alla. Handikappberedningens slutbetänkande. Stockholm: Fritzes offentliga publikationer.

SOU 1995:126. Kostnader för den statliga assistansersättningen. Betänkande av Assistansutredningen. Stockholm: Fritzes offentliga publikationer.

SOU 1999:21. Lindqvists nia: nio vägar att utveckla bemötande av personer med funktionshinder. Stockholm: Fakta info direkt.

SOU 2001:47. En handläggningslag. Stockholm: Fritze Förfarandet hos försäkringskassorna. Stockholm: Fritzes offentliga publikationer.

SOU 2001:56. Funktionshinder och välfärd. Betänkandet av kommittén Välfärdsbokslutet. Stockholm: Fritzes offentliga publikationer.

SOU 2008:77. Möjlighet att leva som andra. Slutbetänkande av LSS-kommittén. Stockholm: Fritzes offentliga publikationer.

Wilson, F. L. (1996). Concepts and issues in comparative politics. London: Prentice Hall.

Wilson, J. Q. (1989). Bureaucracy. New York: Basic Books. 